\title{
Flowline with Resistive Electric Heating System
}

\author{
Alexander Pavlov, Igor Plohov \\ Pskov State University, Faculty of Electric drive and automation systems, Address: Lenin \\ Square 2, Pskov, 180000, Russia
}

\begin{abstract}
The article deals with electric heating systems applied in flowlines for providing their continued operation in wintertime. The problem of obtaining a given distribution of heat output along the length of the pipeline with electric heating system has been solved. It allows to maintain the same temperature sections being in different environments. As the object of investigation a polymer tube with an integrated electrical heating is chosen.
\end{abstract}

Keywords - flowline, electric heating, plastic pipe, hose-cord, equivalent circuit, four-pole.

\section{INTRODUCTION}

To transport natural gas or oil from production areas plants to places for complex preparation and then to the points of connection to the main pipeline flowlines are used [1]. To prevent freezing product (oil and / or gas mixtures) being transported during a cold season the pipelines need heating. The most widely used heating occurs with electric power [2].

Electric pipeline heating system (EPHS) doesn't undergo corrosion, stable to defrosting and can be powered by a common power supply system. Depending on the length of a pipe there are different EPHS (see Table 1). [3]

TABLE 1.

EPHS PIPELINES.

\begin{tabular}{|l|l|l|}
\hline $\begin{array}{l}\text { Length of the } \\
\text { pipeline }\end{array}$ & $\begin{array}{l}\text { Electric pipelines } \\
\text { heating system }\end{array}$ & $\begin{array}{l}\text { The distribution } \\
\text { power network }\end{array}$ \\
\hline up to $100 \mathrm{~m}$ & $\begin{array}{l}\text { self-regulating and } \\
\text { resistance cables }\end{array}$ & network is not needed \\
\cline { 3 - 3 } $200-300 \mathrm{~m}$ & $\begin{array}{l}\text { three-phase cables } \\
\text { connected in star, } \\
\text { including the self- } \\
\text { regulating }\end{array}$ & needed \\
\hline \multirow{2}{*}{$\begin{array}{l}\text { more than } 10 \\
\text { km }\end{array}$} & $\begin{array}{l}\text { non-contact induction } \\
\text { heating (skin-systems) }\end{array}$ & $\begin{array}{l}\text { kmork nowed ned } \\
\text { sides, with } \\
\text { intermediate points }\end{array}$ \\
\hline
\end{tabular}

Nowdays steel and polymer pipelenes are used as flowlines. Flowlines are laid not only in the ground, but also on the surface, where they are aggressively affected by the environment. The use of a polymer pipeline with EPHS as a flowline would solve several problems: to ensure smooth operation of the flowlines at $\mathrm{t}^{\circ}$ below $0^{\circ} \mathrm{C}$, to reduce transportation costs on the pipeline delivery (polymer tube comes in large segments of the reels), to simplify the installation and to improve the protection against aggressive environment. [4]

\section{MATERIALS AND METHODS}

The complex design of steel and plastic pipes has been developed: some pipes have a system of distributed heating, the other include thermal insulation layer, and the third group are provided with reinforcing elements (relevant for polymer pipes) [5, $6,7,8,9]$.

\section{RESULTS AND DISCUSSION}

We have developed a new construction of polymer pipeline, which combines the advantages of hose-cord (multilayer polymer tube with electrical and other conductors) and the original EPHS. The development objective was to obtain the given thermal distribution along the length of the pipeline.

Pipeline with EPHS is hose-cord (Fig. 1.), consisting of an inner working tube 1 (flexible polymer tube, for example of low pressure polyethylene HDPE), on the top of which there is a reinforcing layer 2 . It consists of a steel belt 3 and a layer of the armoring steel wire 4. The reinforcing layer 2 is covered with an intermediate layer 5, which is surrounded by a high-temperature thermal insulation layer 6 (e.g., glass fiber), which also serves as additional reinforcement. Around the hightemperature thermal insulation layer 6 EPHS is laid 7, which is distributed over the entire length of the pipeline. EPHS 7 is made of high resistance conductor 8 (e.g., steel, nichrome, etc.), winded with a step h around the working tube 1 and nonintersecting isolated low-resistance conductors 9 and 10 (e.g., copper) with a step $H$, wherein $H » h$.

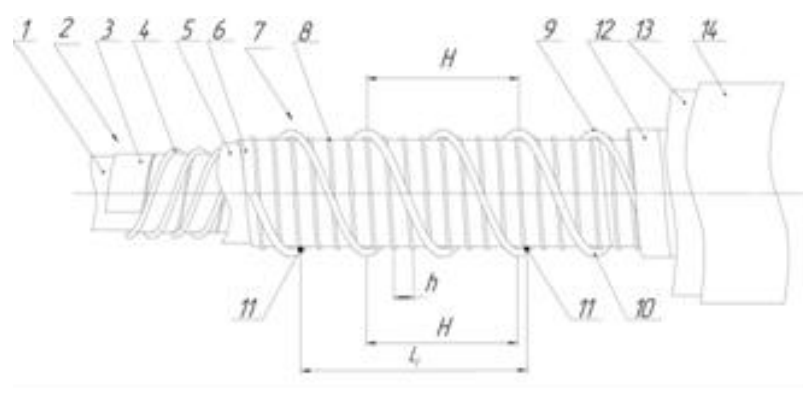

Fig. 1. Construction of the pipeline with electric heating

Low-resistance conductors 9 and 10 are turn is electrically connected (e.g., by soldering, welding) to the high resistance conductor 8 in individual points of their overlapping along the winding 11 spaced at 
different distances Li. EPHS 7 is surrounded by a high temperature insulation layer 12 placed insulating layer 13 (for example, polyethylene foam). On which outer surface the polymeric waterproofing shell 14 (e.g., HDPE) [10].

By applying an electrical voltage to the lowresistance end of the isolated conductors 9 and 10 on EPHS 7 an electric current starts to flow and conductors 8, 9 and 10 are warm up. The electrical equivalent circuit of the EPHS is shown in Fig. 2.

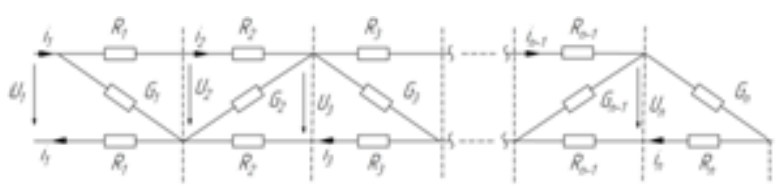

Fig. 2 The complete equivalent circuit of EPHS

EPHS parameter calculation is performed by applying the theory of quadripoles. In this case, the EPHS is given in the form of a chain system (Figure 3), consisting of series-connected sections with discrete longitudinal resistances Rk (low resistance conductor) and the transverse conductivity Gk (highresistance wire), where $\mathrm{k}=1,2 \ldots, \mathrm{n}$ is a section number. The calculation consists in determining the parameters for each subsequent section using the parameters of the previous section by the transition matrix. [11]

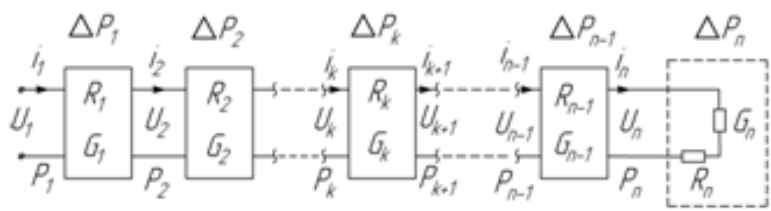

Fig. 3. Chain equivalent circuit of EPHS high-temperature thermal insulation layer 12. Above

\section{CONCLUSIONS}

The pipeline with EPHS is a complex technical solution to build a reliable system of transportation of petroleum products, ensuring trouble-free pumping of crude oil through the territory of the deposit. EPHS allows to get the required distribution of thermal power along the pipeline, which increases the reliability and provides energy saving when employing flowlines.

\section{$\mathrm{V}$ REFERENCES}

[1] F. Mustafin, L. Bykov, A. Gumerov etc, Flowlines and equipment. Moskow: Nedra, 2004.

[2] R. Aliev, V. Belousov, A. Nemudrov, etc, Pipeline transportation of crude oil and gas. Moskow: Nedra, 1988.

[3] N. Khrenkov, "Cable heating super-long pipeline: Select economical scheme," Territory neftegaz, vol. 6, pp. 94-95, 2007.

[4] A. Pavlov, I. Plohov, "Heated-pipe flowlines in the oil industry," Herald PskovGU, vol. 2, 2013

[5] N. Selivanov and V. Selivanov , "Pipe for transporting oil," RU patent 2,453,758 C2, November 27,2010.

[6] A. Robin, "Flexible load-carrying polymer tube and the method of its use," RU patent 2,315,223, Januar 20,2008.

[7] M. Gorilovsky, A. Shmeliov, V. Kovriga, S. Samoilov, I. Gvozdyov, S. Fisherman, I. Pyatin , "Insulated flexible multilayer plastic pipe, not the spread of fire," RU patent 2010,141,068, April 20,2012.

[8] N. Joel, A. Tuan, "Hose with textile reinforcement," RU application for an invention 98,108,039 A, February 20, 2000.

[9] A. Robin, "The device and method of dewaxing oil and gas wells," RU patent 2,273,725 C2, , November 20.

[10] A. Robin, I. Plohov, A. Pavlov, "Pipeline with electric heating system," RU model application 2,013,107,874 A, February 21,2013.

[11] L. Bessonov , "Theory of Electrical: Electrical circuits", Moscow: Higher School, 1978. 